\title{
The Religious Field during the Long Fifteenth Century
}

\section{Framing Religious Change beyond Traditional Paradigms}

\author{
Sabrina Corbellini \\ Rijksuniversiteit Groningen \\ s.corbellini@rug.nl \\ Sita Steckel \\ Westfälische Wilhelms-Universität Münster \\ sita.steckel@uni-muenster.de
}

\begin{abstract}
Introducing a thematic section, this article presents an overview and some of the theoretical considerations resulting from COST Action IS1301, an international research network devoted to the study of lay religious culture during the long fifteenth century. A particular aim of this network was to discuss new European narratives framing the important transformations of lay religious culture during the period c. $135^{\circ}-155^{\circ}-\mathrm{a}$ complex historical process that is still often obscured by the competing older narratives of Reformation, humanism, and Renaissance which shape the historiographical heritage. To get beyond the "methodological nationalism" and "methodological modernism" inherent in older paradigms, the article suggests viewing the transformation of lay religious culture as a long-term process of cultural evolution. It closes with an overview of the most important aspects of this evolutionary process during the long fifteenth century.
\end{abstract}

\section{Keywords}

medieval history - early modern history - lay religious culture - fifteenth century history of religion - historiographical traditions - historical theory 


\section{Introduction: Framing Religious Change beyond Traditional Paradigms}

As several recent contributions show, historians have begun experimenting with histories of the long term again, reversing a trend towards ever more specialized work and a resulting focus on the short term and the micro-historical. These developments are largely driven by a wish for a more active and creative historical engagement. They have often been tied to the diagnosis that criticism alone cannot produce new visions of history, and that the old narratives can ultimately only be replaced - and displaced — by new ones. This move towards new forms of longue durée appears as a challenging but welcome development, as the "short-termism" resulting from the current level of specialization indeed carries the danger of enclosing history so deeply in an ivory tower as to make it practically irrelevant. ${ }^{1}$

On the other hand, the diagnosis of a new need for synthesis and long-term history has not, so far, resulted in any sort of consensus among scholars about the possible formats of such new types of history. There are suggestions for specific areas of history, such as the history of transcultural contacts or materialities, and some intriguing suggestions for the history of religion. The potentials of Digital Humanities and "big data" have been held up and do appear promising. But it seems clear that digital generation and presentation of data will complement rather than replace classical formats of narrative presentation, which must therefore remain the primary basis for experiment. ${ }^{2}$

1 Cf. Jo Guldi and David Armitage, The History Manifesto (Cambridge, 2014); for the history of religion in medieval and early modern Europe especially James Simpson, "Diachronic history and the shortcomings of medieval studies," in Reading the Medieval in Early Modern England, ed. Gordon McMullan and David Matthews (Cambridge, 2007), 17-30; Alexandra Walsham, "Migrations of the Holy: Explaining Religious Change in Medieval and Early Modern Europe," Journal of Medieval and Early Modern Studies 44 (2014), 241-280; see also John H. Arnold, Matthew Hilton and Jan Rüger, "The Challenges of History," in History after Hobsbawm. Writing the Past for the Twenty-First Century, ed. John H. Arnold, Matthew Hilton, and Jan Rüger (Oxford, 2018), 3-14, esp. 5-11.

2 For the history of religion, see Walsham, "Migrations of the Holy" (see above, n. 1), 261265; Fred van Lieburg, "In Saecula Saeculorum. Long-Term Perspectives on Religious History," Church History and Religious Culture 98.3-4 (2018), 319-343; for transcultural history and other approaches see e.g. Lynn Hunt, Writing History in the Global Era (New York, 2014); Margit Mersch, "Transkulturalität, Verflechtung, Hybridisierung. 'Neue' epistemologische Modelle in der Mittelalterforschung," in Transkulturelle Verflechtungsprozesse in der Vormoderne, ed. Wolfram Drews and Christian Scholl [Das Mittelalter-Perspektiven mediävistischer Forschung, Beihefte 3] (Berlin, 2017), 239-251; on Digital humanities, esp. Guldi and Armitage, The History Manifesto (see above, n. 1), 88-116. 
Both the need for new long-term histories and their potential problems are exemplified well by the research field at the centre of this theme section, the religious culture of the laity during the period c. 1350-1550, which we designate in the following as "the long fifteenth century," choosing this fairly neutral term over more suggestive ones. ${ }^{3}$ This research field presents specific challenges: The religious practices of the laity during the late medieval and early modern centuries are of a fascinating and even bewildering richness and variety. Many of the source materials documenting them-such as individually annotated manuscripts and prints, or particular local architectural and artistic arrangements - are challenging in their individuality and specificity. Lay culture is characterized by local and even individual variety, and as a consequence, by complex, intermittent, and often reversible historical developments. Furthermore, any attempt to describe overarching, long-term dynamics of lay culture faces so many regional variations that new findings must be drawn comparatively from massive amounts of religious texts, in a range of vernacular literatures as well as Latin (if we remain focused on Latin Christian culture alone), and finally from objects, art, architecture, and so on. Studying lay religious culture on a larger scale thus demands a high degree of interdisciplinary collaboration. As research has so far mainly been done within the framework of national academic communities (or language communities) and disciplinary specializations, any attempts to establish overarching discussion have to overcome significant differences between distinct academic cultures.

Happily, the research fields contributing to the understanding of lay religious culture have enjoyed considerable attention over decades by now, and the necessary collaborations have been evolving, so that the question of new overarching narratives and perspectives has been asked with increasing frequency. During the years 2013-2017, this discussion gained considerably in intensity due to a large-scale European research network, funded as cost Action Isizo1 "New communities of interpretation. Contexts, strategies and processes of religious transformation in late medieval and early modern Europe" (chaired by Sabrina Corbellini), which organized training and networking activities. ${ }^{4}$

3 Cf. John van Engen, "Multiple Options: The World of the Fifteenth-Century Church," Church History 77 (2008), 257-284, esp. 257-264.

4 The following paragraphs draw not only on discussions within this network, but also on its original proposal co-authored by the 35 Principal investigators, which can be downloaded online (as "Memorandum of Understanding") at https://www.cost.eu/actions/IS1301/ \#tabs|Name:overview (accessed 24.4.2019). 
It was an express aim of this network to bring researchers from different countries and academic communities together to discuss the overarching, European dynamics of lay religious culture of the long fifteenth century, and to generate new historical narratives of a European dimension. Work revolved around the central assumption that there was indeed one central, long-term dynamic that can be traced and documented historically, and which departs significantly from the extant historiography: the emergence of new "communities of interpretation" involving laypeople, which arose in great variety alongside the traditional communities dominated by intellectuals and religious experts. While religious experts relied on their specialized skill and used Latin not only to communicate but also to dominate cultural life through church institutions, schools, and universities, the evolving new communities of interpretation were, in contrast, often formed by an urban laity active in politics, finance, and commerce. They now found ways and spaces in which they could engage with the interpretation of religious texts, either in shared devotional communities including various religious experts, or in associations of laypeople. Over time, such new communities of interpretation took an increasingly active role in the organization of cultural and religious activities and in the production of literary, religious, and scientific texts - and often, they recognized the opportunities offered by reading and writing in the vernacular to further their interests. ${ }^{5}$

As we believe, the lay communities' development of shared interests in the highly diversified religious culture of the period has a significant, but so far underappreciated impact on many areas of religious culture-and on society in general-during the period in question. In particular, it seems that the visible translation of intellectual power and textual creativity to new pragmatically literate groups of lay believers developed so gradually over the later medieval centuries that it has often been recognized only partly, and tends to be subsumed under later trends, obscuring chronologies and causalities. But as we find, this transformation was well under way before the great wave of (Protestant) Bible translations engendered by cultural contacts and reforma-

5 This point is discussed in the Memorandum of Understanding of cost Action 1301 (see above, n. 4). See also Mark Amsler, Affective Literacies: Writing and Multilingualism in the Late Middle Ages (Turnhout, 2011); Jocelyn Wogan-Browne et al., eds., The Idea of the Vernacular. An Anthology of Middle English Literary Theory, 1280-1520 (University Park, PA, 1999). For a socioeconomic analysis of this evolution, see Jan Luiten Van Zanden and Eltjo Buringh, "Charting the 'Rise of the West': Manuscripts and Printed Books in Europe, a long-term perspective from the sixth through the eighteenth centuries," Journal of Economic History 69.2 (2009), 409-445; Eltjo Buringh, Medieval Manuscript Production in the Latin West. Explorations with a Global Database [Global economic history series 6] (Boston, 2011). 
tory impulses - though it had much to do with translation and processes of "vernacularisation" of religious textuality. ${ }^{6}$ It was developing before the invention of the printing press - though it had much to do with media and with a significant growth in participation to processes of textual production and transmission by larger groups within medieval society. It was under way before the Protestant and Catholic Reformations - though these sought to develop or counter it.

While the bulk of the results of this research network is documented in the conventional form of publications speaking to specialized audiences, ${ }^{7}$ some of the members also aimed to take on the challenge contained in the demand for "new European narratives," and to address the topic of long-term developments on a more theoretical level, as this is an issue of fundamental importance for the understanding of lay religious culture. This interest in discussing frameworks for historical transformations largely arose because of the principal challenge to such new narratives - a challenge widespread in historical studies but particularly apparent in the history of religion: The changes focused by the cost Action overlap chronologically with the traditional grand narratives of fundamental religious change around 1500, particularly narratives of Reformation, Renaissance, and humanism, and therefore have to deal with a rather heavy historiographical heritage.

This heritage forms a substantial and foreboding obstacle to the establishment of new perspectives-especially to one which attempts to describe a long-term cultural evolution, whose core dynamics lasted over two hundred years from c. 1350 to 1550 , and which can be traced much further in either chronological direction. However, it is very hard to persuade a broader academic community to let go of older historical master narratives, which have traditionally postulated "revolutions" rather than gradual cultural evolution. ${ }^{8}$

6 Sabrina Corbellini et al., "Challenging the Paradigms: Holy Writ and Lay Readers in Late Medieval Europe," Church History and Religious Culture 93 (2013), 171-188; Eyal Poleg and Laura Light, eds., Form and Function in the Late Medieval Bible (Leiden, 2013); Pavlína Rychterová (ed.), Pursuing a New Order, 2 vols. I: Religious Education in Late Medieval Central and Eastern Central Europe and II: Late Medieval Vernacularization and the Bohemian Reformation [The Medieval translator/Traduire au Moyen Âge 17-18] (Turnhout, 2018-2019).

7 One of the results of the cost Action is the start of the book series "New Communities of Interpretation" (Brepols Publishers). The first collective volumes are expected for 2020 and will present the results of workshops and research meetings held between 2014 and 2017. The volumes will explore the possibilities for conducting research on late medieval religious transformations from a broad pan-European perspective, see e.g. the titles at n. 10 below.

8 On this problem, besides the literature cited above in n. 1, see the nuanced discussions in 
As the consortium of scholars participating in COST Action IS1301 diagnosed at the outset, the many revisions and critical appraisals of the histories of the Reformation and the Renaissance have not always led to changed ways of writing about the role of the laity and the participation of laypeople in religious dynamics. In spite of many advances within specific fieldsespecially the differentiated discussion on the European Reformations themselves ${ }^{9}$ — the period described by the paradoxical juxtaposition "late medieval and early modern" is still often simplistically depicted where lay culture is concerned. All too often, large-scale changes are merely alluded to, via narrative gestures and tropes evoking an impression of cultural discontinuity-a shift from manuscript to print, or from a landscape dominated by papal power and ecclesiastical control to a confessionalized Europe defined by religious and political fragmentation. Innovations are accented by references to dichotomies between Latin and the vernaculars, clerical versus lay or intellectual versus popular culture. The foundations of such descriptions are obviously still to be sought in a historiographical "politics of time" imposing a medieval/modern break, and thus postulating a fundamental cultural difference between the Middle Ages and the Reformation, humanism or the Renaissance. ${ }^{10}$

Viewed in the long-term trajectory discussed by the cost Action, in contrast, the transformations of lay religious cultures from the fourteenth century onwards may have strong links to the religious and political changes of the fifteenth and sixteenth centuries - and are indeed of considerable interest and of importance for scholars interested in them. But their core dynamics-as

Brian Cummings, James Simpson, and Brian Cummings, eds., Cultural Reformations. Medieval and Renaissance in Literary History [Oxford Twenty-First Century Approaches to Literature] (Oxford, New York, 2010); William Caferro, Contesting the Renaissance [Contesting the Past] (Malden, MA, 2011); Berndt Hamm, "Abschied vom Epochendenken in der Reformationsforschung," Zeitschrift für Historische Forschung 39 (2012), 373-411.

9 See e.g. Walsham, "Migrations of the Holy" (see above, n. 1); eadem, "The Reformation and the 'Disenchantment of the World' Reassessed," The Historical Journal 51 (2008), 497528; Matthias Pohlig, "Jubiläumsliteratur? Zum Stand der Reformationsforschung im Jahr 2017," Zeitschrift für Historische Forschung 44 (2017), 213-274; special issue Reformation, Church History and Religious Culture 97, 3-4 (2017).

10 Cf. Kathleen Davis, Periodization and Sovereignty: How Ideas of Feudalism and Secularization Govern the Politics of Time (Philadelphia, 2008); see also e.g. Caferro, Contesting the Renaissance (see above, n. 8), 12-22. Two volumes addressing these issues note are in preparation with the book series "New communities of interpretation" (see above, n. 7), Bridging the Historiographical Divides: Religious Transformations in 'New Communities of Interpretation' in Europe (1350-1570) and Religious Practices and Everyday Life in the Long Fifteenth Century: Interpreting Change and Continuity in Late Medieval and Early Modern Europe. 
we assume: the emergence of new communities of interpretation enabling laypeople to access, discuss, and produce religious knowledge - constitute an independent historical dynamic running over a long time period, which can and should be separated from the prevalent master narratives analytically to avoid misunderstandings and misattributions of cause and effect.

While it is possible to present the new view of lay religious culture emerging from the discussion of the cost Action participants in a straightforward narrative description, it also seemed important to present our findings in a way that might be understandable to a broader interdisciplinary audience, and could thus also contribute to the debate on new forms of long-term history. Though members of the COsT Action also engaged with other audiences, it seemed of particular interest to promote exchange with scholars working on modern religion, either within the context of modern history, literatures or theologies, or within Religious Studies and the sociology of religion.

For this reason, we engaged with particular sociological models of religious transformation, which constitute a widely known meta-language also used by historically oriented scholars and Religious Studies specialists, and which are currently (much like historical models) undergoing a critical revision. ${ }^{11}$ Intriguingly, sociology is (much like history) also experiencing a large-scale intrasociological debate about the reformulation and dynamization of the old theoretical models of modernization and secularization, which has led to much deliberation on potential ways of framing religious change. ${ }^{12}$

While many historians are sceptical about the potential of exchange with sociologists, there are compelling reasons within historical scholarship to reflect on this particular line of interdisciplinary inquiry: Most historical narratives framing our perceptions of religious change are already reliant on socio-

11 For recent discussion of modernization and secularization theories, see e.g. James N. Demerath, "Secularization and Sacralization Deconstructed and Reconstructed," in The SAGE Handbook of the Sociology of Religion, ed. James A. Beckford and Jay Demerath (London, 2007), 57-80; Gurminder K. Bhambra, Rethinking Modernity: Postcolonialism and the Sociological Imagination (Basingstoke, 20o9); Karl Gabriel, Christel Gärtner, and Detlef Pollack, eds., Umstrittene Säkularisierung: Soziologische und historische Analysen zur Differenzierung von Religion und Politik (Berlin, 2014); Detlef Pollack et al., eds., Handbuch Religionssoziologie. Veröffentlichungen der Sektion Religionssoziologie der Deutschen Gesellschaft für Soziologie (Wiesbaden, 2018). A historical approach related to the one presented here is suggested by Klaus Große Kracht, "Das 'katholische Feld.' Perspektiven auf den Katholizismus des 19. und 20. Jahrhunderts im Anschluss an Pierre Bourdieu," in Katholizismus transnational. Beiträge zur Zeitgeschichte und Gegenwart in Westeuropa und den Vereinigten Staaten, ed. Andreas Henkelmann et al. (Münster, 2019), 53-72.

12 Besides the literature cited in n. 11, see also the discussion in Sita Steckel's article below: "Historicizing the Religious Field." 
logical theories or their immediate forebears - but often, these narratives and theories are so old as to have become "naturalized" within history. ${ }^{13}$ There is the nineteenth-century Burckhardtian idea of the Italian Renaissance as a movement of secularization, a shared ancestor of modern historical and sociological theories of modernity. ${ }^{14}$ There is Max Weber's vision of European history as a long-term process of rationalization, societal differentiation, and secularization, a vision whose influence on twentieth-century historians can hardly be overestimated. ${ }^{15}$ There are also various borrowings from the classical period of sociological modernization theory, the 1950s and 196os, which have been adopted into historical narratives. Often, these chronologically late borrowings concerned the long twelfth century as an origin period for the "Rise of the West," but they also appear in many guises in research on the centuries around 1500, for example in intellectual history, which is rather prone to "heroic" narratives of modernization, ${ }^{16}$ and in discussions of church-state relations. ${ }^{17}$

Given this pre-existing relationship and given the parallels apparent in current debates - both historians and sociologists are currently unhappy with traditional paradigms, which appear teleological and linear in their postulation of big historical stages or definite breaks between tradition and modernityit seems productive for historical scholars to look over the fence and evaluate

13 See e.g. the discussion in Garthine Walker, "Modernization," in Writing Early Modern History, ed. Garthine Walker (London, 2005), 25-48. An intriguing analysis of the embedding of modern perspectives in church histories is offered in the recent monograph of Bénédicte Sère, L'Invention de l'église. Essai sur la gènese ecclésiale du politique, entre Moyen Âge et Modernité (Paris, 2019).

14 See e.g. Caferro, Contesting the Renaissance (see above, n. 8).

15 For a recent re-appraisal and adaptation, see David L. D'Avray, Medieval Religious Rationalities. A Weberian Analysis (Cambridge, 2010); idem, Rationalities in History. A Weberian Essay in Comparison (Cambridge, 2010); generally e.g. Thomas Schwinn, Gert Albert, eds., Alte Begriffe-Neue Probleme:Max Webers Soziologie im Lichte aktueller Problemstellungen (Tübingen, 2016).

16 See e.g. Dorothea Weltecke, “'Quod lex christiana impedit addiscere.' Gelehrte zwischen religiöser Verdächtigung und religionskritischer Heroik," in Beiträge zur Kulturgeschichte der Gelehrten im späten Mittelalter, Vorträge und Forschungen, ed. Frank Rexroth (Ostfildern, 2010), 153-184; Sita Steckel, "Säkularisierung, Desakralisierung und Resakralisierung. Transformationen hoch- und spätmittelalterlichen gelehrten Wissens als Ausdifferenzierung von Religion und Politik," in Umstrittene Säkularisierung: Soziologische und historische Analysen zur Differenzierung von Religion und Politik, ed. Karl Gabriel, Christel Gärtner, and Detlef Pollack (Berlin, 2014²), 134-175.

17 See e.g. the critical discussion in Philip S. Gorski, "Was the Confessional Era a Secular Age?," in Umstrittene Säkularisierung: Soziologische und Historische Analysen. Zur Differenzierung von Religion und Politik, ed. Karl Gabriel, Christel Gärtner, and Detlef Pollack (Berlin, 2012), 189-224. 
some innovations which have recently been suggested in the sociology of religion, in order to use these in the debates going on among historians. Drawing on work done in several interdisciplinary cooperations, ${ }^{18}$ we decided to evaluate one particular family of theories, the theory of the religious field, originally developed by Pierre Bourdieu on the basis of Max Weber's work, but recently adapted and reworked by other sociologists such as Philip Gorski and Religious Studies experts such as Astrid Reuter and Nikolas Broy. ${ }^{19}$

Altogether, the present theme section thus pursues a double aim: in this introduction, both some theoretical considerations of the historiographical heritage and current issues (2.) and some core results of the debates of cosT Action IS1301 are presented, summarizing research lines of the framework of the cost Action (3.). In the rest of the theme section, we explore the potential of the theory of the religious field as a tool for historians of European religious history, using the dynamics of lay religious culture during the long fifteenth century to provide examples. After Sita Steckel's article sets out the theoretical framework, the following four case studies from different disciplines, by Ian Johnson (English literature), Margriet Hoogvliet (French literature), Rob Lutton (history), and Elisabeth Salter (cultural history), set out to test it, following a double agenda: The articles constitute original case studies which can illustrate several important dynamics of lay religious culture during our period. But they also explore the usability and limits of the theoretical framework of the religious field.

To avoid confusion, the purpose of such a discussion should be made clear at the outset. While many engagements with theory have primarily asked whether a particular approach can give "impulses" to historically oriented scholarship, this is not the issue here (or rather, not the central issue). It is clear that a theo-

18 This theme section particularly draws on the workshop "The Religious Field in the Long Fifteenth Century. Framing Religious Transformations", organized for cosT Action IS1301 and the Cluster of Excellence "Religion and Politics in Pre-Modern and Modern Cultures" (University of Münster) by Andreas Pietsch and Sita Steckel in May 2016, but also on discussions undertaken in the framework of the "New Religious Histories" sessions at the IMC Leeds from 2014 onwards.

19 Cf. Philip S. Gorski, "Bourdieusian Theory and Historical Analysis. Maps, Mechanisms and Methods," in Pierre Bourdieu and Historical Analysis, ed. idem (Durham, 2013), 327-366; Astrid Reuter, "Charting the boundaries of the religious field: Legal conflicts over religion as struggles over blurring borders," Journal of Religion in Europe 2 (2009), 1-20; ead., Religion in derverrechtlichten Gesellschaft: Rechtskonflikte und öffentliche Kontroversen um Religion als Grenzarbeiten am religiösen Feld [Critical Studies in Religion 5] (Göttingen, 2014), esp. 11-52; Nikolas Broy, "Bourdieu, Weber und Rational Choice: Versuch einer Weiterentwicklung des religiösen Feldmodells am Beispiel Chinas," Zeitschrift für Religionswissenschaft 25 (2017), 287-324. See further below Steckel's article. 
retical framework of the scale of field theory, which contains macro-theoretical elements, cannot be "applied" directly to historical sources. Nor would this add much to our inquiry in every case. Rather, the direction of transfer is the other way around: we aim to discuss the potential of this theoretical approach for the specific purpose of establishing an interdisciplinary explanatory framework, understandable for non-specialists.

But such a framework must first and foremost be adaptable to historical research itself, and the case studies test our approach in this respect, exploring whether it is indeed possible to use an adapted form of sociological field theory as a meta-language for historical study. For the reasons stated above, and elaborated in more detail in the next paragraphs, our question was whether field theory can help us to formulate our results in a meta-language, and whether the inherent questions and long-term perspectives of this particular framework are useful as a scaffold for historical work on pre-modern religion. Several of the case studies therefore particularly evaluate what parts and metaphors of field theory appear productive. They also suggest how this framework might be adapted for purposes of historical scholarship, and - particularly in the case of Elisabeth Salter's and Margriet Hoogvliet's contributions-combine and contrast it with other historical or sociological approaches.

\section{Confronting the Challenges of Methodological Nationalism and Methodological Modernism}

As suggested above, the international scholarly network of COST Action IS1301 engaged with the current discussion on new large-scale narratives for practical reasons, namely the fragmentation of relevant research into many different sub-fields and national/linguistic academic communities. But the issue of larger perspectives and patterns for historical writing is also a theoretical one, which confronts historians generally at the moment, and has other "tributary" debates which converge with the overall question, for example current debates on periodization in a globalized world, which also force us to rethink the grand lines and trajectories we are accustomed to. ${ }^{20}$

20 See e.g. the different remarks to this effect in Guldi and Armitage, The History Manifesto (see above, n. 1); Arnold, Hilton, and Rüger, "The Challenges of History" (see above, n. 1); Walsham, "Migrations of the Holy" (see above, n. 1); Van Lieburg, "In Saecula Saeculorum" (see above, n. 2). Challenges to traditional periodization, especially the medieval/modern divide, increasingly also come from the field of global history and non-Christian cultures, see e.g. the (partially contradictory) views in Sebastian Conrad, What is global history? 
From this vantage point, it seems apparent that new demands for longterm histories are not necessarily voiced to countermand earlier debates which caused the turn away from grand narratives and towards cultural history. ${ }^{21}$ There is no question of going "back" to large-scale history of an old type, but towards new forms.

To clarify our point, some shifts within the fields of the political history of the pre-modern period can serve as an example: As various scholars have pointed out, European histories of the political can profit quite substantially from a "provincializing" of Europe and a widening of its horizon towards the global, or at least the transnational. ${ }^{22}$ This shift helps to re-frame local and regional histories of the pre-modern period within their transcultural dynamics, and produces important insights about both local and transcultural dynamics which had not been visible while historians thought in national terms. As has also become clear, however, such a widening of the horizon comes at the cost of older models of history: If we allow that the world has many regions, and thus many histories, organizing our narratives and models of periodization along only one of these regions (such as western Europe) makes increasingly less sense. Historians are instead finding ways to historicize and combine local, regional, and trans-regional dynamics and their interplay, and use narrative formats incorporating elements of transcultural or comparative history to achieve "connected" or "entangled histories." ${ }^{23}$ Even though the theoretical and

(Princeton, 2016); Catherine Holmes and Naomi Standen, "Introduction:Towards a Global Middle Ages," Past and Present Supplement 13 (2018), 1-44; Thomas Bauer, Warum es kein islamisches Mittelalter gab. Das Erbe der Antike und der Orient (Munich, 2018); Thomas Maissen and Barbara Mittler, eds., Why China Did Not Have a Renaissance — and Why That Matters. An Interdisciplinary Dialogue (Berlin, 2018).

21 For the dynamics of this transformation, see Walsham, "Migrations of the Holy" (see above, n. 1), 251-26o.

22 Cf. Dipesh Chakrabarty, Provincializing Europe: Postcolonial Thought and Historical Difference (New Edition) (Princeton, 2009); see e.g. the overviews Pierre-Yves Saunier, Transnational History [Theory and History] (London, 2013); Lynn Hunt, Writing History in the Global Era (New York, 2014).

23 See e.g. Sanjay Subrahmanyam, "Connected Histories: Notes towards a Reconfiguration of Early Modern Eurasia," Modern Asian Studies 31.3 (1997), 735-762; Dorothea Weltecke, "Space, Entanglement and Decentralisation: On How to Narrate the Transcultural History of Christianity (550 to 135 O CE)," in Locating Religions: Contact, Diversity, and Translocality, Dynamics in the History of Religions, ed. Reinhold Glei and Nikolas Jaspert (Leiden, 2017), 315-344; Antje Flüchter and Jivanta Schöttli, eds., The Dynamics of Transculturality. Concepts and Institutions in Motion [Transcultural Research-Heidelberg Studies on Asia and Europe in a Global Context] (New York, 2014); on religious dynamics, see esp. Volkhard Krech, 2012. "Dynamics in the History of Religions-Preliminary Considerations on Aspects of a Research Programme," in Dynamics in the History of Religions Between Asia 
methodological niceties of these approaches have been discussed and clarified substantially by now, historians currently face the challenge to carve out new spatial and chronological fields of inquiry which cut across traditional demarcations, and to actually write texts which present a multi-linear and multiperspectival history in narrative shape-as narrative in the classical formats of monograph or article necessarily remains at least formally linear. ${ }^{24}$

Within the history of religion, this challenge to historicize older, compartmentalized historiographies and to find new meaningful frameworks and narratives presents similar problems and dilemmas. Viewed more closely, however, religious history actually faces more challenges than just the need to overcome national frameworks: There is of course a "methodological nationalism," and this needs to be tackled by developing transnational approaches. ${ }^{25}$ But models of periodization and the way we narrate religious change also present a problem, which may be called "methodological modernism" here. ${ }^{26}$ Finally, religious histories are by now shaped by disciplinary identities-i.e. by research specializations - as much as by national and confessional/religious historiographies. While this introductory article has no room for an overview of important master narratives concerning lay culture during the late medieval and early modern period, it is clear that practically all current research necessarily moves on groundwork (and often within particular sub-fields) shaped by the complex mixture of national and confessional historiographies, modernization theories, and disciplinary and individual interests and trajectories which has characterized relevant academic scholarship between the nineteenth and the late twentieth centuries.

The best-acknowledged issue inherent in the relevant traditions is that of "methodological nationalism":27 During the eighteenth and nineteenth cen-

and Europe: Encounters, Notions, and Comparative Perspectives, ed. Volkhard Krech and Marion Steinicke (Leiden, 2012), 15-70.

24 Cf. Weltecke, "Space, Entanglement" (see above, n. 23); Sita Steckel, "Story Street is a OneWay Street. Concluding Thoughts on Cultural Entanglement and Historical Narration," in Transkulturelle Verflechtungsprozesse in der Vormoderne, ed. Wolfram Drews and Christian Scholl [Das Mittelalter. Perspektiven mediävistischer Forschung. Beihefte 3], (Berlin, 2016), 252-275.

25 Besides Weltecke, “Space, Entanglement” (see above n. 23), see also Klaus Koschorke (ed.), Etappen der Globalisierung in christentumsgeschichtlicher Perspektive. Phases of globalization in the history of christianity, Studien zur aussereuropäischen Christentumsgeschichte (Asien, Afrika, Lateinamerika) (Wiesbaden, 2012).

26 We are indebted to Christina Brauner (Tübingen) for the term "methodological modernism," to be discussed in one of her future publications.

27 See e.g. Jani Marjanen, "Undermining Methodological Nationalism. Histoire croisée of Concepts as Transnational History," in Transnational Political Spaces. Agents- 
turies (at the latest), the great lines and teleologies inherent in the confessional "sacred histories" of the early modern period were complicated by the impact of competing national identities. ${ }^{28}$ But historians of the nineteenth century typically produced their narratives in competition to each other, mirroring contemporary competitiveness and a resurgence of confessional churches embattled by new secularist leanings. As a result, we have always been confronted with many large-scale narratives concerning the religious history of Europe, which are entangled with each other in an uneasy state of tension: Rather than just one "Protestant paradigm" and one history of the Reformation, for example, we have many national versions of them. While this "nationalization" of historical master narratives has detracted considerably from their clarity, their multiplication - and paradoxically even the multiplication of narratives postulating a "Proto-Reformation" like the English or Czech ones-has only served to cement the importance of the underlying narrative arc. ${ }^{29}$ Whether historians want this or not, words have their own force, and the ideas inherent in older "Reformation" historiography_-generally of a radical or revolutionary upheaval and a religious renewal confronting "decay" - are being reinforced with each new adaptation of the term. ${ }^{30}$ Counterintuitively, the many attempts to nuance, distinguish, or (on the other hand) connect different aspects and regional dynamics of reform and Reformation thus also have the unintended consequence of reinforcing older perspectives - especially outside of the specialized research field of Reformation history. ${ }^{31}$

Structures - Encounters, ed. Mathias Albert et al. [History of Political Communication 18] (Frankfurt am Main, 2009), 239-263.

28 See e.g. Patrick J. Geary and Gábor Klaniczay, Manufacturing Middle Ages: Entangled History of Medievalism in Nineteenth-Century Europe [National Cultivation of Culture 6] (Leiden, 2013); Gábor Klaniczay, Michaela Werner, and Otto Gecser, eds., Multiple Antiquities, Multiple Modernities: Ancient Histories in Nineteenth Century European Cultures (Frankfurt, 2011); Robert J.W. Evans and Guy P. Marchal, eds., The Uses of the Middle Ages in Modern European States: History, Nationhood and the Search for Origins [Writing the Nation] (Basingstoke, 2011).

29 See the discussion in Walsham, "Migrations of the Holy" (see above, n. 1), 244-246; eadem, "The Reformation and the 'Disenchantment of the World' Reassessed," The Historical Journal 51 (2008), 497-528.

30 This argument is made for related terms by Bernhard Jussen, "Wer falsch spricht, denkt falsch. Warum Antike, Mittelalter und Neuzeit in die Wissenschaftsgeschichte gehören," in Spekulative Theorien, Kontroversen, Paradigmenwechsel, ed. Matthias Steinmetz [Debatte. Berlin-Brandenburgische Akademie der Wissenschaften 17] (Berlin, 2017), 38-45.

31 This is one of the problems of narrative accounts attempting to bridge late medieval reforms and early modern Reformations, which typically cannot escape a clear teleology reducing medieval developments to forerunners, see e.g. Stephen Ozment, The Age of 
This is one of the principal reasons why historians have begun to introduce new terms to the study of this particular field - for example by contrasting "traditional" and "translated religion" rather than developing the invariably somewhat "whiggish" history of "reform" / "Reformation,"32 or by speaking about "confessionalization" as a trans-confessional process rather than verbally prioritizing the "Reformation" over the (invariably later, and thus lesser) "CounterReformation." ${ }^{33}$ We may note in passing how such attempts to find new terminologies have by themselves led to diverging research traditions: The former strategy, typical for the revisionist paradigm of English Reformation history, has successfully nuanced traditional views by pointing out trajectories and causalities which differed widely from earlier explanations. But it also furthered a tendency towards specialization and national differentiation. In contrast, research on confessionalization proved conducive to a transnational and comparative perspective, as it seeks to point out the similarities as well as the differences among regional patterns of confessionalization-but this also carried a danger of overstressing similarities, ${ }^{34}$ and not all national academic communities have been equally enthusiastic in receiving this research design.

The task of developing comparative and comparable approaches thus still confronts new histories of European lay religious culture: While we know of many regional similarities and shared socioeconomic structures-for example, shared processes of urbanization and increasing levels of literacy - we also know that regional differences do not allow us to simply postulate "European" dimensions for every phenomenon associated with lay religious culture. Building on a growing number of important contributions, historians of religion thus still face the task of writing "connected histories" of specific religious phenomena across different European regions - and across their changing transcultural networks to each other, and to Asia, Africa, and the Americas. As transcultural and transreligious contacts and dynamics between Europe and other continents are experiencing a significant (and highly welcome) boom, it seems

Reform. 1250-1550. An Intellectual and Religious History of Late Medieval and Reformation Europe (New Haven, NJ, 1980); Pierre Chaunu, Le temps des réformes: Histoire réligieuse et systeme de la civilisation. La crise de la chrétienté-l'éclatement (1250-1550) (Paris, 1974); on this problem, see more recently Hamm, "Abschied vom Epochendenken" (see above, n. 8). With this impetus e.g. Eamon Duffy, The Stripping of the Altars: Traditional Religion in England; c. 1400-c. 1580 (New Haven, 2005); the contrast "traditional—-translated" in John Bossy, Christianity in the West, 1400-1700 (Oxford, 1985).

33 See the overviews in Kaspar von Greyerz et al., eds., Interkonfessionalität-Transkonfessionalität-binnenkonfessionelle Pluralität: neue Forschungen zur Konfessionalisierungsthese [Schriften des Vereins für Reformationsgeschichte 201] (Gütersloh, 2003).

Thus the overall argument of Greyerz et al., eds., Interkonfessionalität (see above, n. 33). 
important to point out that a history connecting the religious dynamics within the diverging regions of Europe with their distinct religious profiles- the Scandinavian North and the Baltic, Western Europe, East Central Europe, and the different constellations facing the Mediterranean and Atlantic — remains to be written in various important respects.

Yet there is also a second problem which any new attempts at such connected histories are facing, labelled here with the short-hand reference "methodological modernism": Given the need for historians to make themselves understood to broader interdisciplinary audiences, and particularly to experts for modern religion, Religious Studies and the sociology of religion besides other historically oriented scholars, it seems important to note that many "framing" strategies for historical work concerning the late medieval and early modern period remain indebted to the concept of modernization. ${ }^{35}$ The narrative structure of modernization theories, which typically link and contrast a bundle of "modern" and "traditional" features and distribute them according to a pre-modern/modern contrast, may be more or less obvious in the many diverging narratives of (Proto-)Reformation. But it is essentially inbuilt in histories of the Renaissance and indeed of the "Early Modern" period, which are both predicated on the assumption (formulated against earlier Reformation paradigms) that there was a slow but significant change from around 1350 or 1500 , transforming the medieval into the modern world. ${ }^{36}$ With the ongoing academic professionalization, and thus the increasing specialization of research during the twentieth century, other, more particular narratives of modernization began to be added to the traditional "grand" narratives, and began overlaying and partially masking them within various research fields and sub-disciplines: Modernization could be linked to new forms of education like humanism, to the printing press, and even to particular religious dynamics like the Devotio Moderna. ${ }^{37}$ As specialization is by now fully established, the references to modernity and modernization are often reduced to vague narrative gestures setting up the importance and relevance of a given book in the introduction and concluding chapter. Yet this framing of pre-modern history (and particularly of specialized history focused on the short-term) as a history of

35 Cf. Walker, "Modernization" (see above, n. 13); Carol Symes, "When We Talk about Modernity," American Historical Review 116 (2011), 715-726. On the development of modernization narratives in sociology and history, see esp. Wolfgang Knöbl, Die Kontingenz der Moderne: Wege in Europa, Asien und Amerika, Theorie und Gesellschaft (Frankfurt am Main, 2007).

36 See e.g. Justus Nipperdey, "Die Terminologie von Epochen-Überlegungen am Beispiel Frühe Neuzeit/'early modern'," Berichte zur Wissenschaftsgeschichte 38 (2015), 170-185.

See Corbellini et al., "Challenging the Paradigms" (see above, n. 6), 178-186. 
cultural identity with modernity rather than one of cultural alterity ${ }^{38}$ remains one of the most important strategies of generating relevance for pre-modern history today.

In a parallel to the competing national views of religious history, however, all these competing narratives of modernization remain in a curious mutual tension: As the alleged points of departure for modernity have multiplied, the particular narratives attached to this transformation have become extremely varied, differentiated, and thus also rather vague. Yet again, paradoxically, the one overarching commonality of historiographies indebted to "methodological modernism" is their insistence and reinforcement of a break between medieval and modern. But the many postulated points of origin for this break are not typically confronted with each other, in the way in which some national developments have been confronted with each other to separate transnational and overarching dynamics from national and particular ones.

While the analogy to transnational history may carry us only so far, it does suggest that some of the operations and shifts which have successfully transformed national into transnational and transcultural histories may also be necessary with regard to periodization - or put more generally, with regard to the way cultural history comes to view and represent processes of short-, mid- and long-term duration. On the level of space, a transcultural perspective ultimately engages with historical processes on different spatial and geographical levels - and should, ideally, distinguish historically between processes of local significance and processes with regional or supra-regional dimensions at a particular moment in time. On the level of time, a cultural history engaging with the long term as well as the mid- and short-term ranges similarly needs to engage with different historical processes to determine how short-, midand long-term dynamics play together in given historical contexts. Given the richness of already extant research on all sorts of slow and fast transformations, the success of such processes of distinction appears largely dependent on new views of the sources, but also on the critical evaluation and successful connection of extant layers of historiographical heritage - and, of course, on successful interdisciplinary exchange allowing specialists for one particular thread of cultural history to access other threads.

One of the suggestions of the cost Action was therefore to tackle this task more explicitly, and to develop a more integrated perspective on the many related religious transformations in fourteenth- to sixteenth-century European

38 On the tension between histories emphasizing alterity or identity see Paul Freedman, Gabrielle M. Spiegel, "Medievalisms Old and New: The Rediscovery of Alterity in North American Medieval Studies," American Historical Review 103 (1998), 677-704. 
history which cut across older narratives. To fully appreciate the transformation of lay religious culture during the fourteenth, fifteenth, and sixteenth centuries and to narrate it meaningfully, it seems particularly important to drop the fixation on turning points and "revolutions" so typical for the many overlapping stories of modernization told about this period, and to allow more room for long-term and gradual developments.

To use the analogy to transnational history a last time, one might indeed argue that older national histories typically constructed their cultural identities by artificially homogenizing the nation in question and suppressing or eliding the existence of cultural "others" and of hybridity. Similarly, older narratives of religious history often tied cultural identities to one revolutionary change or decisive shift, and thus displayed a tendency to artificially homogenize time in conformity with a before/after dichotomy. ${ }^{39}$ Yet in reality, most of the religious dynamics so far connected to modernity undergo episodic, multiform, and complex developments. The most obvious paradox created by this complex and multiform change is the largely synchronic appearance of historical dynamics which have been separated into distinct and even opposed historical master narratives - the religious renewal (and even to a degree: religious radicalization) of the Reformations, and the apparent secularization and religious individualization labelled today as the Renaissance.

As we suggest, it may therefore be helpful to develop frameworks and metaphors which can accommodate this variety of historical changes. ${ }^{40}$ For our particular field of lay religious culture, it might for example be fruitful to appreciate the religious transformations of the late medieval and early modern period as a slow cultural "evolution" rather than revolution. This means borrowing from theories of societal evolution, which have in turn taken inspiration from theories of biological evolution. ${ }^{41}$ Adapting such theories further to the aims of historical study might offer a helpful scaffold for the appreciation of lay religious culture: Relevant theories of societal evolution describe it as a complex, large-

39 Cf. Simpson, "Diachronic History" (see above, n. 1); Davis, Periodization (see above, n. 10); Caferro, Contesting the Renaissance (see above, n. 8), 1-30.

40 Cf. Walsham, "Migrations of the Holy" (see above, n. 1), 261-265.

41 See e.g. Klaus Eder, "Kulturelle Evolution und Epochenschwellen-Richtungsbestimmungen und Periodisierungen kultureller Entwicklungen," in Handbuch der Kulturwissenschaften, ed. Friedrich Jäger and Jürgen Straub, 3 vols (Stuttgart, 2005), 1:417-430 or the overview in Linnda R. Caporael, James R. Griesemer, William C. Wimsatt, eds., Developing Scaffolds in Evolution, Culture, and Cognition [Vienna series in theoretical biology] (Cambridge, MA, 2014); we are indebted to Daniel S. Brooks for the latter reference, and important critical remarks on sociological theories of societal evolution, which we hope to follow up in the future. 
scale, and undirected process, in which distinct steps-variation of cultural patterns, social selection among these variations, and ensuing stabilization of new pattern(s) - are repeated many times in recurring episodes, leading either to cultural diversification or to other forms of transformation. In the dynamic continuum of lay religious life during the fourteenth to sixteenth centuries, we witness such episodes over and over again: New variations of religious practice emerged due to local, regional or transcultural impulses, changing social contexts or media. Social and political processes led to the selection of some innovations over others - or at times to an affirmation of established patterns, or even a reduction and destruction of variations - and so finally to sudden or gradual stabilizations of new religious options.

The diversity, ambiguity, constant change, and flexibility characteristic of lay religious life during our period, which has often made it quite hard for research to summarize and describe, in fact underlines its genuinely evolutionary, undirected nature: We are clearly not witnessing a single transformation directed by the intentions of any one elite or insurgent lay group, but a more complicated, largely unintended pattern of smaller and larger changes, in which bottomup impulses of lay engagement interacted with repeated initiatives of competing religious experts and elites, producing many re-negotiations of similar ideas and practices, with some successful religious innovations, but also many regional peculiarities and less durable alternatives. In this process, recurring attempts to stabilize, renew, or control religiosity all across Europe first led to the emergence of a multiform, somewhat messy, and largely unplanned landscape of multiple religious "options" during the long fifteenth century. ${ }^{42}$ Battles over religious and political hegemony characterized this landscape from the beginning, but eventually led to a period of renewed institutionalization characterized by heightened political influence on religion, as local political elites forced the stabilization of new, regionalized constellations of religious diversity across Europe during the course of the sixteenth century. ${ }^{43}$ Though obvious in many respects, it seems important to note that some aspects of these transformations appear grounded in gradual, deep-seated social and socioeconomic processes, while others constitute different consequences of these developments triggered by acute conflicts or socio-political developments on

42 See Van Engen, "Multiple Options" (see above, n. 3).

43 See e.g. Berndt Hamm, "Normative Zentrierung im 15. und 16. Jahrhundert. Beobachtungen zu Religiosität, Theologie und Ikonologie”, in Religiosität im späten Mittelalter: Spannungspole, Neuaufbrüche, Normierungen, ed. Reinhold Friedrich and Wolfgang Simon [Spätmittelalter, Humanismus, Reformation 54] (Tübingen, 2011), 3-40. 
the micro-historical level — and as such, small divergences eventually grew into diverging cultural patterns building on the shared foundations. To understand these processes, it seems important to find a new balance between long-term changes of a structural nature and the more short-lived dynamics of cultural innovation and adaptation.

\section{Dynamics of Lay Religious Culture during the Long Fifteenth Century (c. 1350-1550)}

The activities within the framework of the cost Action made clear that at least two seminal processes supporting the described translation of intellectual power and textual creativity can be highlighted. From the fourteenth century onwards, we firstly observe a gradual erosion of the established cultural hierarchy placing religious elites over the laity, as this hierarchy had not only been predicated on the clergy's exclusive power to dispense the sacraments, but also on their access to the sacred scriptures and scholarly expertise transmitted in Latin. ${ }^{44}$ We also observe the generalized presence of alternative channels of transmission of religious knowledge, next to the traditional liturgical activities performed by members of the clergy. Even though a division of labour between laity and clergy and a regime of sacramental mediation of the divine was ultimately conserved, the balance of power shifted considerably towards the laity as two complementing processes of knowledge transfer took hold: laypeople now adapted new devotional practices based on (and complemented with) religious reading often performed in the domestic and private space, and mastered the discourses and cultural vocabularies allowing them to evaluate and critique religious experts and to contribute to the production and dissemination of religious texts.

Taken together, the debates and gradually emerging new social forms resulting from this process led to a second result: a considerable diversification of religious experience within the ambit of European Christianity. This development of "multiple options" (John van Engen) can be understood as a religious "pluralization," insofar as it forced the laity into decision-making processes and thus into something of a "religious market" dynamic, in which open or unacknowledged competition among the plurality of extant religious observances

44 See e.g. Willem Williams-Krapp, "The Erosion of a Monopoly: German Religious Literature in the Fifteenth Century," in The Vernacular Spirit, ed. Renate Blumenfeld-Kosinski, Duncan Robertson, and Nancy Bradley Warren (New York, 2002), 139-159. 
and lifeforms lent new weight to lay religious decisions. ${ }^{45}$ This shift proved hard to reverse, even in repeated attempts at "normative centering" and religious persecution, beginning in the fifteenth century and leading up to the processes of confessionalization and institutionalization of religious alternatives visible from the sixteenth century onwards. ${ }^{46}$

Within the framework of the cost Action activities, these two briefly sketched general lines evolved into the formulation of four research hypotheses that could potentially further impact the research agenda, and that are at present developed in individual and collaborative research conducted by the members of the cost Action.

\subsection{The Impact of Religious Textualities and the Creation of New Communities of Interpretation}

The long fifteenth century seems to have witnessed a marked increase in the size of the religious field, with more laypeople actively engaging with extant structures of religiosity. ${ }^{47}$ Given historical source materials and the absence to date of systematic studies of this phenomenon, this development cannot be described in quantitative terms. Rather, extant research and new results emerging from the совт meetings also suggest a qualitative change, namely that engagement in religious matters intensified during the late Middle Ages.

In comparison with earlier phases of high engagement of European laypeople with religion, structural changes in the religious field during the long fifteenth century appear highly impacted by one centrally important dynamic: during the period in question, many more people could read-about $30 \%$ of the population in England, according to research cited by James Simpson, and possibly even more in strongly urbanised regions of Italy, France, Germany, and the Low Countries. ${ }^{48}$ At the same time and in close interrelation with this trend, existing religious traditions which had hitherto been transmitted in Latin and in highly specialized discourses were made accessible in new formats and media, and often translated into vernacular languages..$^{49}$ Extant and inno-

45 Van Engen, "Multiple Options" (see above, n. 3). See also the discussion on the religious field and its "market" dynamics in Steckel's article below.

46 Cf. Hamm, "Normative Zentrierung” (see above, n. 43).

47 The following paragraphs make occasional references to the concept of the religious field, discussed below and in the articles in this thematic issue.

48 James Simpson, Reform and Cultural Revolution (Oxford, 2004), 5. It should moreover be stressed that access to texts is not just restricted to literate participants. Forms of oral and aural reading could significantly amplify the "reading" public.

49 See for example the collaborative volumes Rychterová (ed.), Pursuing a New Order (see above, n. 6), with contributions by several members of the cost Action; Vincent Gille- 
vative traditions of religious expertise could therefore impact religious practice in new ways, prompting the emergence of new types of religious literacies among laypeople. On this basis, a range of new communities of interpretation grew up. While engaging with new types of religious texts or materialities in traditional or new social settings, laypeople could take both receptive and more active roles in their own spiritual affairs, either engaging in shared devotional cultures with religious experts (of orthodox or heterodox stripes), or participating in lay communities located between and across older pastoral structures, at times led by lay "active readers." ${ }^{\circ 0} \mathrm{~A}$ clear example of this process is the growing impact of confraternities in the organization of religious life and in the promotion of devotional activities. ${ }^{51}$

Situating these observations in a pan-European approach, we are of course aware of the risks of generalization and of regional and chronological differences. Yet especially if we take a long view, and include transformations ranging from the tenth or eleventh to the seventeenth centuries, it can be stated with confidence that we witness various phases of local, regional, or supra-regional religious renewal, which left visible results in the sources we have included in our research activities, in particular vernacular religious texts. The (textual) sources documenting lay religious activity during the long fifteenth century give a clear impression of increasing activity and heightened lay engagement in the religious life and underline the importance of participation also through activities that contemplated texts, reading, and interpretation. It is for example not by mere chance that the production of textual material grew exponentially in the course of the fifteenth century, leading the way to the success of the printing press. ${ }^{52}$

It is important to stress that at least in parts, this development seems connected to the economic, social, and political rise of urban laities during our period: the shift does not present itself as laypeople "discovering" religion and entering the religious field for the first time. Rather, some lay groups clearly disposed of increasing resources (economic, but also intellectual resources, as

spie and Kantik Ghosh, eds., After Arundel. Religious Writing in Fifteenth-Century England [Medieval church studies 21] (Turnhout, 2011).

5o Cf. Sabrina Corbellini, Margriet Hoogvliet, and Bart Ramakers, eds., Discovering the Riches of the Word. Religious Reading in Late Medieval and Early Modern Europe (Leiden, 2015).

$5^{1} \quad$ For a recent overview of late medieval and early modern confraternities, see Konrad Eisenbichler (ed.), A Companion to Medieval and Early Modern Confraternities [Brill's companions to the Christian tradition 83] (Leiden, 2019).

52 Cf. Buringh, Medieval Manuscript Production (see above, n. 5); Elisabeth Salter, Popular Reading in English c. 1400-1600 (Manchester, 2012). 
well as disposable time) which allowed them to step out of fairly passive roles and engage with religion more actively. This translated into an adaptation process of the religious field, allowing the development and structural growth of new forms of religious discourse and practice highly suited to such newly active groups. One example of such new forms is discussed in Margriet Hoogvliet's article on lay religious poetry below.

On this basis, it should also be clear that we neither postulate that this was the first or the last time that a comparable transformation can be observed. On the contrary - from a medievalist perspective, there are, for example, strong parallels to the situation of the long twelfth century, which shows an intriguingly similar transformation (and thus calls up Alexandra Walsham's suggestion that we witness recurring "back and forth" dynamics or "re-negotiations" which are nevertheless not repetitive or cyclical ${ }^{53}$ ). The long twelfth century also witnessed a sustained phase of high lay interest in religiosity, which generated a renewal of traditional religious lifeforms and encouraged religious innovations. Moreover, many transformations of the long twelfth century were, just like their fifteenth-century counterparts, clearly facilitated by a strong increase in literacy, ultimately tied to the growth of political and economic structures in emerging cityscapes and denser networks of lordship. But the political and social frame impacting the religious field at that time led to different results. While most twelfth-century religious movements within Latin Christianity became new religious orders, or, failing to achieve ecclesiastical approval, illicit heretical communities, the 1215 prohibition of further new religious orders narrowed this channel of possibilities. Also, literacy levels seem to lie much lower during the twelfth than during the fifteenth century and access to vernacular religious textualities was less generalized. While we do witness increased use of the vernacular languages in pastoral contexts during the twelfth century, this had different consequences, and did not affect large strata of the medieval population as in the fifteenth century. More importantly, the distance between laity and educated experts actually grew significantly during the twelfth century, as new normative bodies of texts in Latin emerged, especially in theology and canon law, and became the exclusive province of experts specifically schooled for their interpretation.

53 Cf. Walsham, "Migrations of the Holy" (see above, n. 1), 264; Sita Steckel, "Differenzierung jenseits der Moderne. Eine Debatte zu mittelalterlicher Religion und moderner Differenzierungstheorie," Frühmittelalterliche Studien 47 (2013), 35-8o. 


\subsection{Spaces and Location of the Religious}

If we look at the location of the religious field, it could be argued that in addition to many public venues, a number of additional places of religious debate and instruction grew up, leading to the creation of a wide array of "lieux de savoir religieux," and thus enabling a significant transformation in the space of religion. ${ }^{54}$ Reflections on spatial approaches to the study of religion, religious activities, and religious reading have been among the most discussed themes during the cost Action activities and have led to the development of new research strategies that are well exemplified in this thematic issue. ${ }^{55}$ The focus on spatial approaches in the study of religion is moreover very much in line with one of the main goals of the Action, the reflection on and the use of research methodologies that allow for a truly pan-European research approach and stimulate collaboration and exchange across linguistic and national boundaries. ${ }^{56}$

One of the main and essential transformations in the spatiality of religion during the long fifteenth century is the growing importance of the domestic and private spheres of laypeople, which seem to have become connected to religious activity in an unprecedented way. Very much in the line of the "multiple options" epitomized in John van Engen's seminal study, this transformation did not (or not only) lead to a creation of alternative spaces (domestic and private) in opposition to the "official" religious and liturgical spaces. Our research testifies that personal and domestic religious activities were typically not meant to create a distance between the believers and the liturgical activ-

54 The phrase "lieux de savoir religieux" has been inspired by the work of the French historian Christian Jacob. See Christian Jacob, Que'est-ce qu'un lieu de savoir? (Marseille, 2014) and the forthcoming article Sabrina Corbellini, "Reconstructing Religious Places of Knowledge in Late Medieval Europe," in Über Religion entscheiden. Religiöse Optionen und Alternativen im mittelalterlichen und frühneuzeitlichen Christentum, ed. Matthias Pohlig and Sita Steckel (in preparation for $202 \mathrm{O}$ ).

55 See for example some of the collaborative research projects resulting from the cosT Action, the Nwo-project Cities of Readers (https://www.rug.nl/research/icog/research/ researchgroups/cities-of-readers), the HERA JPR project PUblic REnaissance (http://her anet.info/projects/public-spaces-culture-and-integration-in-europe/public-renaissance -urban-cultures-of-public-space-between-early-modern-europe-and-the-present-pure); the project Espaces Urbains, Dynamiques et Identités religieuses dans l'Europe Moderne, led by Elise Boillet (Tours).

$5^{6}$ One of the cost meetings (Groningen, November 2015) has been devoted to the study of spatial approaches, and a volume on European religious networks is in preparation. Moreover, the development of spatial approaches to the study of late medieval religious could possibly enhance collaboration with social scientist and stimulate a longue durée approach to religion and participation in religious activities and textualities. 
ities, but resulted from the enhanced participation described above. As discussed in the articles of Elisabeth Salter and Rob Lutton in this theme section, this "relocation" of religion and the importance of the domestic space cannot be overestimated. 57

A seminal result of the cost Action was also to acknowledge that this transformation was to a great extent stimulated by the secular and regular clergy in their religious instruction to the laity. Ian Johnson's article below shows that lay critical engagement with scripture was at times so openly encouraged by ecclesiastical office-holders as to create problems for the clergy. Overviews of late medieval preaching and of catechetical treatises ad usum laicorum also stress the extent to which the late medieval laity was stimulated to perform religious activities in the domestic space, or to function as intermediaries between the clergy and fellow lay believers. Medieval preachers for example stressed the importance of taking notes from sermons and sharing their main lines with other members of the household in order to further propagate religious instruction. ${ }^{58}$ This point reinforces an essential aspect of late medieval society that emerged clearly during the cost activities: the importance of taking the aspect of "community" and of "collaboration" into consideration as a connecting thread in the study of late medieval religiosity. As we found, late medieval religiosity presents itself as the result of exchange and mutual influence, both along the vertical line (religious professional to laity; laity to religious professional) and horizontal line of learning (peer to peer education).59

\subsection{The Diversity of the Religious Field: Multiple Options}

While we assume that the religious field configurations of the various European regions were generally diverse and plural during the medieval and early modern centuries, the long fifteenth century appears marked by a particular

57 The link between domestic space and religion has been addressed in two recent volumes, Abigail Brundin, Deborah Howard, and Mary Laven, eds., The Sacred Home in Renaissance Italy (Oxford, 2018); Maya Corry, Marco Faini, and Alessia Meneghin, eds., Domestic Devotions in Early Modern Italy (Leiden, 2018).

$5^{8}$ A case in point are the sermons of the Franciscan Cherubino da Spoleto describing in his sermons a complete theory of religious communication in which the laity is playing an essential role, see Sabrina Corbellini, "Creating Domestic Sacred Space: Religious Reading in Late Medieval and Early Modern Italy," Domestic Devotions in Early Modern Italy, ed. Maya Corry, Marco Faini, and Alessia Meneghin (Leiden, 2018) 295-309.

59 For a recent publication building on the concept of "horizontal learning," see Micol Long, Tjamke Snijders, and Steven Vanderputten, eds., Horizontal Learning in the High Middle Ages. Peer-to-Peer Knowledge Transfer in Religious Communities (Amsterdam, 2019), with a view to the longue durée especially Sita Steckel, "Concluding observations. Horizontal, hierarchical, and community-oriented learning in a wider perspective" (there $235^{-256}$ ). 
quality of such diversity: Besides the co-existence of different religions and the activity of heterodox movements in several European regions, we also find a high number of options for orthodox religiosity. As John van Engen has argued, these "multiple options" on the way towards salvation catered to a broad variety of social groups, educational preferences, and religious dispositions (and thus probably helped to engage diverse lay groups). This could again be seen as a culmination of prior tendencies, as the diversity of options was, paradoxically, partially a product of overlapping or competing attempts to enforce orthodoxy by various elites over the previous decades and centuries. The multiplication of options led to an increasing tension and could trigger new forms of pluralization as well as "normative centering" and forms of persecution. Religious diversity thus has its own particular tensions during the long fifteenth century, not least in the interaction of Christian and non-Christian actors and practices, where we see important instances of interplay between Jewish, Christian, and Muslim religiosities and lay pieties evolving during the long fifteenth centurybut also, of course, the forcible separation of hybridized cultures and persecution of non-Christians, which reached high points as well. ${ }^{60}$

As demonstrated in Rob Lutton's article, late medieval religion is also characterized by malleability and instability that often permeates related manifestations, even within the same geographical and linguistic area. This diversity and multiplicity does not, however, appear as a contrast to the previous conclusions involving the description of general tendencies: as multiple options of religious activity can actually be detected in the same place at the same time, it is essential to stress that the attention for general patterns and developments should not lead to an oversimplification and lack of attention for local and specific developments. Unique combinations of political, social, and geographical variables could indeed impact religious transformations.

6o See e.g. Katrin Kogman-Appel, Jewish Book Art between Islam and Christianity: the Decoration of Hebrew Bibles in Medieval Spain [The Medieval and early modern Iberian world 19] (Leiden, Boston 2004); Carmen Caballero-Navas and Esperanza Alfonso, eds., Late Medieval Jewish Identities: Iberia and Beyond [The new Middle Ages] (New York, 2010); Ephraim Shoham-Steiner (Ed.), Intricate Interfaith Networks in the Middle Ages: Quotidian Jewish-Christian Contacts [Studies in the history of daily life 80o-16oo] (Turnhout, 2016); for polemics and persecution Mónica Colominas Aparicio, Religious Polemics of the Muslims of Late Medieval Christian Iberia: Identity and Religious Authority in Mudejar Islam [The Medieval and Early Modern Iberian World 64] (Leiden, 2018); Mercedes GarcíaArenal and Gerard Wiegers, "Introduction," in Polemical Encounters: Christians, Jews, and Muslims in Iberia and Beyond, ed. Mercedes García-Arenal and Gerard Wiegers [Iberian Encounter and exchange, 475-1755] (University Park, PA, 2019), 1-21. 
For this reason, the discussion of the delicate balance between the micro and the macro-historical level also resounds in the essays presented in this theme section, especially in Elisabeth Salter's contribution. This question has been at the very core of the consortium's research activities and it is possibly one of the main research challenges that need to be addressed in the near future, especially in the research efforts linking the transformations of the late medieval to the early modern period.

\subsection{A Dynamization of the Sacred in Discourse}

Combined with the growing engagement of laypeople participating in communities of interpretation, the diversity of religious elites and options triggered a "dynamization" of the sacred. Laypeople now learned to use evaluative vocabularies debating the merit of different religious practices and lifestyles and discussed the way religion impacted various other fields. While these vocabularies often go back to prior centuries, particularly the long twelfth century with its increase in orthodox and heterodox diversity, ${ }^{61}$ their process of appropriation was amplified in the long fifteenth century by new forms of (often vernacular) didactic and imaginative literature and multi-media adaptations, as described in all of the case studies discussed below. Along these lines, it is important to take into consideration that the process of vernacularization of religious textualities and performances, either by the regular and secular clergy for non-Latinate lay public or by laypeople themselves, triggered a process of reflection on the vernacular as a language of religion and of salvation. The creation and the use of a "sacred vernacular" dramatically shortened the distance between the "holy" and the "lay" and sparked a religious dynamic that markedly affected social, cultural, political, and religious life.

This effect of high intra-religious diversity in fifteenth-century Christianity can in a way be compared to the effects of pluralization on the modern religious field, as described by Peter L. Berger and others-but the dynamizing and relativizing effects discussed as consequences of pluralization by Berger become visible on the level of specific religious practices, not of religious belief systems as a whole. ${ }^{62}$ If individuals had to choose one of several religious options

61 See e.g. Robert I. Moore, The Formation of a Persecuting Society: Authority and Deviance in Western Europe 950-1250 (Oxford, 2007²); Guy Geltner, The Making of Medieval Antifraternalism: Polemic, Violence, Deviance, and Remembrance (Oxford, 2012); Sita Steckel, "Satirical Depictions of Monastic Life," in The Cambridge History of Western Monasticism, ed. Alison I. Beach and Isabelle Cochelin (Cambridge, forthcoming), 1154-1170; Peter A. Dykema and Heiko A. Oberman, eds., Anticlericalism in Late Medieval and Early Modern Europe [Studies in Medieval and Reformation Traditions 51] (Leiden, 1993).

62 Cf. Peter L. Berger, The Many Altars of Modernity: Toward a Paradigm for Religion in a Plu- 
and possibly even had to debate the practices offered by competing elites, with all their merits and demerits, religious engagement could not be a matter of course, and the authority of religious specialists was subject to critical evaluation rather than unquestioning acceptance. This practice of questioning, evaluating, and selecting before accepting was further stimulated by the powerful presence of groups, communities, and confraternities literally "bound by [religious] words." ${ }^{63}$ As a matter of fact, the new religious dynamics of the long fifteenth century are often collective manifestation of groups, from the few members of a family to the large audience of a preacher, engaged in a common and joint search for new forms of expression for religious feelings and aspirations.

\section{Acknowledgments}

Research underlying this article was funded by cosT Action IS1301, "New communities of interpretation. Contexts, strategies and processes of late medieval and early modern religious transformations", by the Volkswagen Foundation Dilthey Fellowship Grant "Diversitas religionum. Thirteenth-century foundations of European discourses of religious diversity" and the Exzellenzcluster "Religion and politics in pre-modern and modern cultures" at wwu Münster, funded by Deutsche Forschungsgemeinschaft. The latter two generously funded this Open Access publication.

ralist Age (Boston, 2014) and the discussion in Sita Steckel, "Problematische Prozesse. Die mittelalterliche Inquisition als Fallbeispiel der Problematisierung religiösen Entscheidens im Mittelalter," Frühmittelalterliche Studien $5^{2}$ (2018), 365-399, there 376.

63 Peter Howard, "Bound by Words: Creating Belief and Community in Renaissance Florence," in Brotherhood and Boundaries. Fraternità e barriere, ed. Stefania Pastore, Adriano Prosperi, and Nicholas Terpstra (Florence, 2011), 249-258. 